\title{
VINEYARDS IN THE REGION OF STRADEN (AUSTRIA) - ELEMENT OF THE AGRARIAN CULTURAL LANDSCAPE
}

\author{
Ileana Cristina CRĂCIUN, Camelia Ina GAVRA \\ "Babeş-Bolyai" University Cluj-Napoca, Faculty of Geography, Romania
}

\begin{abstract}
Vineyards in the region of Straden represent the element outlining the agrarian cultural landscape of this area. Viticulture was introduced by the Romans, and it has been practiced from time immemorial both for the wine, used in the daily meals, and for the religious practices. Viticulture represents a source of income for the people, who try hard to maintain a typical wine country in their characteristic way.
\end{abstract}

Key Words: vineyards, region of Straden, elements, agrarian cultural landscape.

\section{Introduction}

Within the context of a more and more aggressive globalization, shown in different areas as economy, culture, architecture or language, accepting, researching and preserving the agrarian cultural landscape sets as a necessity for an efficient preservation (and through it) of the local, regional and even national cultural identity.

Thus, it is necessary to accept and use the meaning (definition) given to the cultural landscape by the European Landscape Convention; the landscape means "an area, as perceived by people, whose character is the result of the action and interaction of natural and/or human factors" (The European Landscape Convention, 2000).

The natural (physical) characteristics of the area are influenced by the local natural aspects as climate, soil, water resources, mineral resources etc.; these are attributes of the natural landscape which establish the landmark of human actions development, each anthropic activity inducing changes, the visible sign of man's interference being represented by the cultural landscape.

\section{Methodological approach}

Elaborating this article has been a complex process, consisting of interdependent stages, each one with a precise function:

The preparatory stage (data accumulation) consisted of:

- Formulating the research objective: Determining the elements of the wine-growing cultural landscape in the region of Straden;

- "Invest in people!" PhD candidate with studentship in "Project co-financed from the European Social Fund through the Sectoral Operational Programme for Human Resources Development 2007-2013";

- Delimiting the territory to be examined;

- Choosing the best research methods and measures;

- Consulting the bibliographic sources referring to the territory indicated (official, public or archive documents; unofficial written sources - the press, periodicals, books; statistical 
sources - rough or processed), text selection, methodical reading, summarizing and comparing the texts and examining the unwritten sources (objects and other materials); study of the cartographic sources.

The analysis stage mainly consisted of:

- Storage and systematization of data;

- Processing of data from the first stage.

Within the last stage, which is deliberative, the elements of the cultural landscape, the theoretical conclusions, and the text editing have been emphasized.

The methods used for studying the elements of the landscape belonging to the region above mentioned "have constituted themselves in a group of (practical) procedures and (theoretical) measures chosen in order to economically obtain" (Muntele, p. 25) the desired results. Choosing the above mentioned methods is the first stage of the research (data accumulation), these methods being used throughout the entire research process.

The cultural landscape registry method was chosen and used as a specific method for the cultural landscape research. Using this method in this case (the systematic registration of its elements in a hierarchically structured registry) conclusive data have been obtained, which were constituted in the basic structure for analyzing and classifying the elements of the wine growing cultural landscape in the region of Straden.

The registry includes specific sections, where - through functional and/or practical approaches - data related to the geographical coordinates, dimensions, structures, features, functions and evaluation criteria of the cultural landscape elements are underlined.

In order to obtain the results initially proposed, methods specific to Geography or other sciences were also used, such as: bibliographical documentation, through which we accumulated "useful data (related to certain objects, processes and phenomena) which is then used especially for drawing up the evolution of the phenomena until the execution of the respective studies" (Cocean, 2005, p. 132); the analysis method, which facilitated us the knowledge of elements of the wine growing cultural landscape through their psychological decomposition and deep study both of the component parts, with their quantitative and qualitative characteristics, and of their place and role within the whole; the cartographic method (representation of the studied region on the thematic map) and the statistical method, "useful in the processing of data obtained through the other mentioned methods".

\section{Region of Straden. Physical-geographical particularities}

The region of Straden, also called the Wine Country, is located in the South-East part of Steiermark province (Austria) - a land characterized by diversity both from the landscape point of view and from the cultural point of view. This province is composed of eight localities: Straden, Kronnersdorf, Hart, Nägelsdorf, Schwabau, Wassen, Wieden and Markt (Fig. 1).

The locality of Straden is situated over the Sulz and Poppendorf rivers valley, on a range of hills extending up to the Mur valley in the South. These are also the elements dominating the Straden landscape. Marktl is located at the extremity of the Sulz river valley in the East.

The prominent range of hills in the West is forming the substratum on which Straden town is 

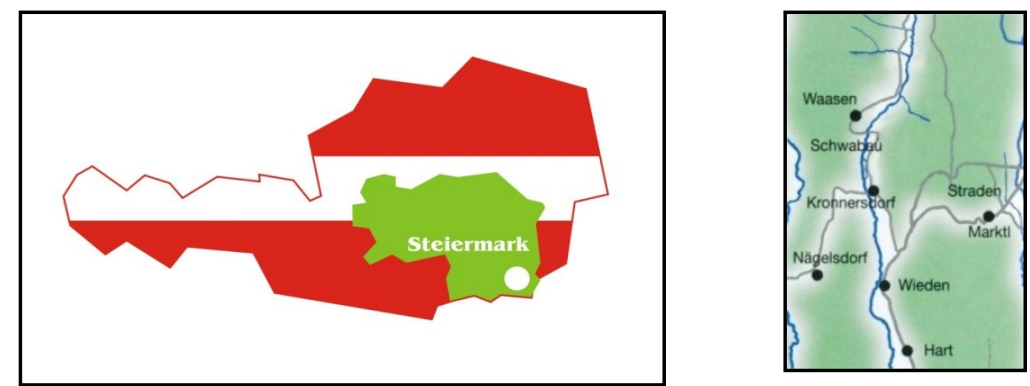

Fig. 1 - Region of Straden, Steiermark province (Austria). Positioning of the region in the territory

built, with its three churches noticeable from far away. In the valley of Poppendorf river there are the localities Waasen, Schwabau, Kronnersdorf, Wieden and Hart. The west side of Straden is formed by the range of hills extending between the Poppendorf river valley and the Gnas valley, as well as the valley of Gnas river itself, where the locality of Nägelsdorf lies (M. Messner, 1999, p. 12). The ranges of hills and valleys, as well as the volcanoes in the neighbourhood, still dominating the morphology of this region, are the final result of a history persisting for millions of years.

In this region, climate is characterized by warm summers and cold, moderate winters. The average annual temperature is of $8^{\circ} \mathrm{C}$. In July, the warmest month of the year, the average temperature is of $18.9^{\circ} \mathrm{C}$, while in January, the colder month, $-2.4^{\circ} \mathrm{C}$. The fall-outs are in sufficient quantities. Fog is present between $30-50$ days / year, and the speed of wind is generally low. The risk of freezing is insignificant, as altitude increases. Because of this reason surfaces planted with vine are present in the region of Straden in their great majority on slopes, and due to the special "requirements" for temperature and sun exposure, they are oriented mainly towards south, but also towards east and west.

In this area, there are mainly brown soils on loose sediments. Due to indurated strata, these soils tend to form a dam of the underground water. We encounter here the pseudogleic soil, which is a soil tending to moisten or dry, depending on the quantity of precipitations. If the soil moistens it expands, and if it dries out it decreases its volume; thus, during draught, fissures appear in the soil, this fact affecting the roots of the existing vegetation. Brown and red clay is often found on the volcanic rocks. These soils were formed during much warmer climatic conditions of the Tertiary, that is why they are also called relict soils (Brigitte Schicho, 1999, p. 17). Alongside the climate, soil represents the basis of the wine (agricultural) production, as well as of the landscape scenery.

\section{Wine-growing cultures - Element of the agrarian cultural landscape}

General aspects. The extra-muros field in the region of Straden is being used in its majority for agriculture and for extending the forest surfaces. The peasants' and foresters' way of life has a powerful effect on the shape of rural landscapes, as well as on the temporary changes of the landscape aspect. "Ploughing, sowing, harvesting of crops; cutting of hay or gathering silage; moving herds or flocks within or across the land; planting, thinning, felling of forest trees these bring change, colour, pattern and movement to the landscape, often in ways that are special to a particular place" (European Council for the Village and Small Town, 2006, p. 10). 
This region presents a diversity of elements of the agrarian cultural landscape, such as: vineyards, orchards, corn fields etc.; however the image of the agrarian cultural landscape is marked out by the presence of the vine cultures, which gives its specific character.

The first great blooming of the vine in Steiermark province is determined by the decree of emperor Probus (3-rd century after Christ), which abolished the Italian monopoly of wine production and permitted the cultivation of noble vine outside Italy. In 1526, viticulture is extending considerably, but the wars of those times caused its decline. Maria Theresia (1740 $1780)$ and Joseph $(1780-1790)$ took measures for the reconsolidation of viticulture.

In the last decades, the region of Straden has had significant growth in the vine culture (Lackner, Ficzko, 1999, p. 272).

Classifying the elements of the wine cultural landscape. The vineyard cultural landscape is emphasized through its characteristic elements, which contribute in a certain way to outlining the specific character of the region. According to the criteria of shape (Glink, Meyer, Schottke, 2007), there are three main types of elements:

1. Dot-shaped elements. They are represented in the landscape by the concrete pillars (with height of 2 metres), which have the purpose to sustain the wires tiding the vine.

2. Row-shaped elements. They are represented by the rows formed by pillars, wire and vine, but also by the grass surface separating the two neighbouring parcels (in the shape of a grass layer, wider than the usual distance between rows, that is $2.50 \mathrm{~m}$ ).

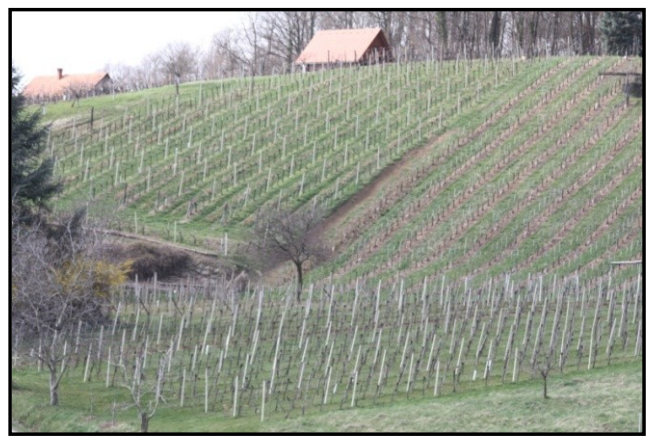

Fig. 2 - Vineyard (rows of pillars), Hart locality, Steiermark province (Austria)
3. Area-shaped elements. They are noticeable within the landscape in the shape of parcels of land occupied with vine and of buildings for processing, preserving and commercializing the wine products.

Vine gardens are usually located on inclined surfaces, of rectangular or trapezoidal shape, their dimenssions varying between $200 \mathrm{~m}^{2}-2$ hectares, as well as between $3-6$ hectares or even more.

Elements of the wine cultural landscape of the Region of Straden (Austria)

\begin{tabular}{|l|l|l|}
\hline Dot-shaped elements & \multicolumn{1}{|c|}{ Row-shaped elements } & Area-shaped elements (surface) \\
\hline - concrete pillars & $\begin{array}{l}\text { - rows of pillars, wire and vine } \\
\text { - rows of grass for separating } \\
\text { the parcels }\end{array}$ & $\begin{array}{l}\text { - parcels of land occupied with } \\
\text { vine } \\
- \text { buildings for the processing } \\
\text { preserving and commercializing } \\
\text { the wine products (buildings) }\end{array}$ \\
\hline
\end{tabular}




\section{Method of maintaining the vineyards throughout the year}

Along with the mechanization and rationalization of the viticulture (after 1956), a reorientation of the culture was imposed, from the culture of stakes, which supposed much more manual labour, to the wire culture, also called high or sophisticated, which makes possible the automatic processing of the surfaces (Lackner, Ficzko, 1999, p. 272).

In this way, the first work is cutting the vine. Right after harvesting the workers cut the vine. Normally, this process takes place if the weather allows it (if there is no risk of freezing), in the month of January, respectively February. The main vine is tied up and fixed to the wire.

The flowering takes place in April. At that time grass is growing between the cultivated rows, grass which will be cut in order to cover the vines cut before with an organic layer of grass. Every vine that will grow afterwords will clamber and fix to the wire culture. It will currently be sprayed with insecticide, depending on the weather conditions or on disease cases. If the new shoots or the leafage grow too high, their points will be cut. Grass is cut constantly, and then the vine roots are covered with an organic layer of grass.

If the weather allows, at the end of August - beginning of September the harvesting of the new variety of grapes will begin.

Applying the wire culture and harvesting involves an unceasing process. In the past, the workers harvasting grapes cut them and put them into wooden or metal buckets; the buckets were transported to the crusher, which was found - in most cases - near vineyards or in cellars. Nowadays the harvest (the grapes) is treated much more gently. The grapes are put into plastic caskets, gently and without being pressed; they are transported using a vehicle and they are immediately processed. Today modern devices in the cellars are: a) the Decorticator: it separates the individual grape berries from the cluster; b) the must pump: it pumps the must gently into the crusher; c) the crusher: it functions hydraulically (hydraulic grape press), implying the best handling for the harvest, so that it is properly preserved. In the case of the wire culture, modern devices have multiple functions: for example grass can be cut and chopped (in order to be used as organic manure), and at the same time, through spraying, diseases can be controlled, respectively parasites specific to vine cultures.

\section{Viticulture in the statistical data}

Presently, the wine growers administer vineyards occupying a surface of 33.44 hectares. These vineyards (vine gardens) belong to various owners, and they are associated in enterprises.

Table 2

Vineyards - surfaces in hectares

\begin{tabular}{|c|c|c|c|c|c|c|c|}
\hline Region & \multicolumn{2}{|c|}{ Total vineyards } & \multicolumn{5}{|c|}{ Vineyards according to the production capacity } \\
\hline \multirow{3}{*}{ Straden } & Enteprises & Surface & Product & & $\begin{array}{l}\text { Still } \\
\text { unprod }\end{array}$ & & $\begin{array}{l}\text { Total of the } \\
\text { planted }\end{array}$ \\
\hline & \multirow[b]{2}{*}{67} & \multirow[b]{2}{*}{33.44} & $\begin{array}{l}\text { White } \\
\text { wine }\end{array}$ & $\begin{array}{l}\text { Red } \\
\text { wine }\end{array}$ & $\begin{array}{l}\text { White } \\
\text { wine }\end{array}$ & $\begin{array}{l}\text { Red } \\
\text { wine }\end{array}$ & \multirow[b]{2}{*}{33.44} \\
\hline & & & 25.99 & 6.27 & 1.04 & 0.15 & \\
\hline
\end{tabular}

According to the Statistik Österreich, Wien 2000 
According to the existing statistical data, there are a number of 67 wine growing enterprises registered, which merchandise their different varieties of wines in taverns (wine cellars), (Buschenschänke).

The commercialization of wine growing products takes place in various different phases:

- Selling grapes. The bigger wine cellars buy, right after harvesting, grapes from vineyards or from the collecting places. The price is established individually depending on the variety or on the sugar content.

- Selling from the grape crusher: unfermented wine, must, is sold directly to the buyers. It is used for juice or for wine production.

- Selling from barrels: Fermented wine is sold in big quantities from containers, barrels of small sizes or other recipients, from the yard or the cellar of the wine grower. Distilleries also sell big quantities.

- Selling bottles of wine: Wine as the finite product (garnished, filtered) is poured into bottles of $0.75-1.00 \mathrm{I}$, rarely in bottles of 2 liters, labelled and offered for sell.

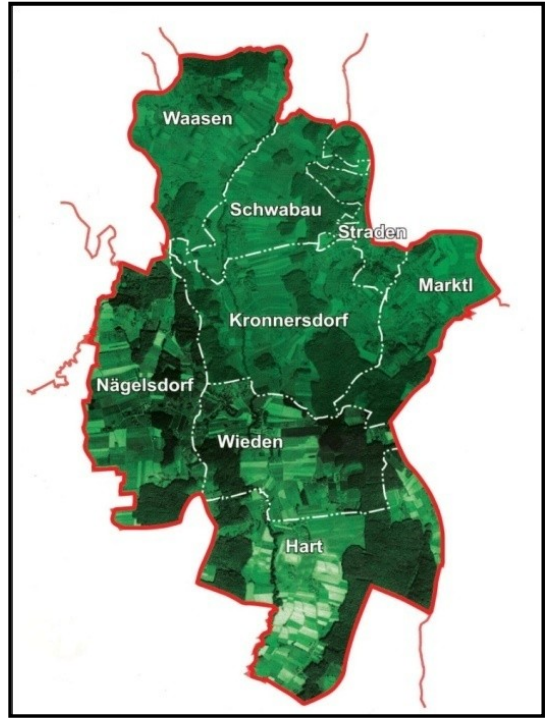

Fig. 3 - The 8 localities of Straden, where we find wine growing enterprises

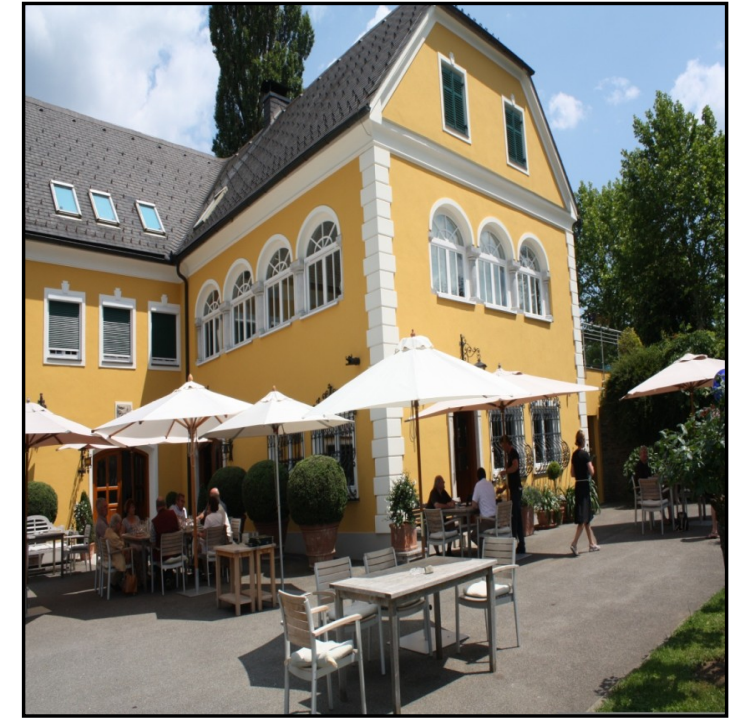

Fig. 4 - Tavern, Wieden locality, Steiermark province (Austria)

The right of the wine growers to sell wine from their own production or other products produced in their own yard, derives from a law of the Habsburg monarchy, issued during the reign of Joseph the Second (from 1784).

Out of the total $f$ the surfaces of 33.44 hectares planted with vine, we can notice the presence of white grape varieties, which occupy a surface of 27.02 hectares, being followed by the red grape varieties, with 6.41 hectares. As for the vine varieties in this region, the Welsh Riesling is the dominant one, followed by the Burgundy white wine, Müller-Thurgau and Riesling (Table 2). 
Surfaces cultivated with varieties of white grapes (Surfaces in hectares)

Table 3

\begin{tabular}{|l|r|}
\hline Total surface & $\mathbf{2 7 . 0 2}$ \\
\hline Bouvier & - \\
\hline Frühroter Veltliner (Malvasier) & - \\
\hline Furmint & - \\
\hline Goldburger & 0.13 \\
\hline Grauer Burgunder (Pinot Gris, Ruländer) & 1.54 \\
\hline Grüner Veltliner (Weissgipftler) & - \\
\hline Jubiläumsrebe & - \\
\hline Müller-Thurgau (Riesling x Sylvaner Rivander) & 4.85 \\
\hline Muskateller (Gelber und Roter Muskateller) & 0.54 \\
\hline Muskat-Ottonel & 0.10 \\
\hline Neuburger & - \\
\hline Roter Veltliner & - \\
\hline Rotgipfler & - \\
\hline Sauvignion Blanc (Muskat-Sylvaner) & 2.64 \\
\hline Scheurebe (Sämling 88) & 1.28 \\
\hline Sylvaner (Grüner Sylvaner) & 0.21 \\
\hline Traminer (Gewürztraminer, Roter Traminer) & 1.24 \\
\hline Weisser Burgunder (Weissburgunder, Pinot Blanc, Klevner) und & $\mathbf{5 . 7 5}$ \\
Chardonnay (Feinburgunder, Morillon) & \\
\hline Weisser Riesling (Riesling, Rheinriesling) & 1.29 \\
\hline Welschriesling & $\mathbf{7 . 2 4}$ \\
\hline Zierfandler (Spätrot) & - \\
\hline Other varieties of white grapes & 0.22 \\
\hline
\end{tabular}

According to Statistik Österreich, Wien 2000

Surfaces cultivated with varieties of red grapes (Surfaces in hectares)

\begin{tabular}{|l|r|}
\hline Total surface & 6.41 \\
\hline Blauburger & 0.66 \\
\hline $\begin{array}{l}\text { Blauer Burgunder (Blauer Spätburgunder, Blauburgun- } \\
\text { der, Pinot Noir) }\end{array}$ & - \\
\hline Blauer Portugieser & - \\
\hline Blauer Wildbacher & 0.50 \\
\hline Blau Främkisch & 0.41 \\
\hline Cabernet Frank & - \\
\hline Cabernet Sauvignon & 0.39 \\
\hline Merlot & - \\
\hline St. Laurent & - \\
\hline Zweigelt (Blauer Zweigelt, Rotburger) & $\mathbf{4 . 4 0}$ \\
\hline Other varieties of red grapes & 0.06 \\
\hline
\end{tabular}

According to Statistik Österreich, Wien 2000.

The Pannonian proximity offers space to the prosperity of the red wine, the largest surface being occupied by the Zweigelt blau (Table 3). It is important to mention that the quality wines obtained in these areas are internationally recognized.

Wine from this "wine growing country" has succeeded due to the fact that wine growers have kept its quality through consequent struggle, in order to obtain a remarkable fame at national 
and international presentations, at competitions and assessments.

\section{Conclusions}

Vineyards represent the element outlining the agrarian cultural landscape of this region.

In this area, the wine growers have tried very hard and will always try to preserve their land as a typical wine country, through quality wine products, to promote them by advertising and to commercialize them.

The quality vineyards, prospering in these abrupt environment, mark out the image of the regional cultural landscape, giving its distinctive character.

\section{References}

COCEAN P. (2005), Geografie regională, Editura Presa Universitară Clujeană, ClujNapoca.

GLINK C., MEYER H-H., SCHOTTKE Maja (2007), Historical Cultural Landscapes in Romania Mapping and registration of endangered traditional cultural landscape elements in Transy/vania, in Romanian Review of Regional Studies, volume III, Number 2, Editura Presa Universitară Clujeană, Cluj-Napoca.

LACKNER J., FICZKO F. (1999), Weinbauverein Straden, Straden, Weishaupt-Verlag, A-8342 Gnas, im Auftrag der Marktgemeinde Straden, Austria.

MESSNER M. (1999), Naturräumliche Gegebenheiten, Straden, Weishaupt-Verlag, A8342 Gnas, im Auftrag der Marktgemeinde Straden, Austria.

MUNTELE I. (2005), Metodologia cercetării geografice regionale, Note de curs pentru uzul studenților, Universitatea „Alex.I.Cuza” Iaşi, Facultatea de Geografie şi Geologie.

SCHICHO Brigitte (1999), Geographie der Gemeinde Straden, Straden, WeishauptVerlag, A-8342 Gnas, im Auftrag der Marktgemeinde Straden, Austria.

STOICA Flavia, SCHREIBER W. (2008), Peisaje culturale istorice, Editura Argonaut Cluj-Napoca.

${ }^{* * \star}$ Weinbau, Interesantes aus verschiedenen Zeitungen, gesammelt von Josef Lackner, Schriftführer im „Weinbauverein Straden“.

***European Council for the Village and small Town (2006), Landscape identification, Looking, Thinking and Feeling, ECOVAST Landscape identification.

${ }^{* * *}$ Statistical data, Marktgemeindeamt Straden, Austria.

${ }^{* * *}$ Marktgemeinde STRADEN, Ortsplan mit Gemeindeinformation, Strassennetz, Hausnummernübersicht, Infrastruktur, Druck: Marko Druck $\mathrm{GmbH}$.

${ }^{* * *}$ Der Weibau in Österreich 1999 (2000), Herausgeber Statistik Österreich, Bundesanstalt öffentlichen Rechts, Wien.

***Österreichs Weinreiseführer, Band 2 Steiermark (1997), Druck- und Verlagsges M. B.

H. NFG. KG, Klosterneuburg.

${ }^{* * *}$ Steiermark, Herausgeber: Verlag Foto Hruby, A-8740 Zeltweg.

Received at : 20.04.2010

Revised at: 20.05.2010

Accepted for publication at: 9.06 .2010 